\title{
DKI Jakarta Governor Policy in Revoking the 2018 Jakarta North Coast Reclamation Permit
}

\author{
Suryani ${ }^{1}$, Agus Nugraha ${ }^{2}$, Azizah Putri ${ }^{3}$ \\ \{suryani@uinjkt.ac.id ${ }^{1}$, agus.nugraha@uinjkt.ac.id², azizah.pr15@mhs.uinjkt.ac.id³ \\ Universitas Islam Negeri Syarif Hidayatullah Jakarta, Indonesia ${ }^{123}$
}

\begin{abstract}
This study analyzes the DKI Jakarta governor in revoking the 2018 north coast reclamation permit. This study aims to look at the factors of policy change in the context of Jakarta's north coast reclamation and see further about the impact of the revocation of the 2018 Jakarta north coast reclamation permit. This study was conducted through a literature study and interviews. The reclamation policy of the north coast of Jakarta is interesting to study because there was a change in the public policy from the Ahok period to the revocation of the 2018 Jakarta north coast reclamation permit in Anies period. This study utilizes a theoretical framework of public policy and public-private-private partnerships in the perspective of good governance. From the results of the analysis using these two theories, it can be concluded that the change in public policy certainly has a new impact after the implementation of the policy. In this case, it appears that the DKI Jakarta Provincial Government has implemented the policy following the applicable governance provisions and principles. The new policy needs further processes to legalize the policy so there are no claims that allow the resumption of the reclamation projects.
\end{abstract}

Keywords: Reclamation, Permit Revocation, Public Policy.

\section{Introduction}

In the 2017 Jakarta Regional Head Election, the candidate pair of the governor and deputy governor, Anies Baswedan and Sandiaga Uno stated 23 promises if they were elected. The campaign promises range from extending the benefits of the Jakarta Smart Card (KJP) to terminating the reclamation project on the north coast of Jakarta [1]. The termination of the reclamation project was immediately highlighted by the opposing candidate pair of Basuki Tjahaja Purnama (Ahok) and Djarot.

Reclamation of the north coast of Jakarta during the office term of Ahok in 2014 to 2017 has obtained permission for the implementation of the reclamation through 4 decrees and 1 regulation. Ahok assessed that the construction of 17 Jakarta Bay reclamation islands could benefit DKI Jakarta. However, in 2016, problems arose related to the reclamation of the north coast of Jakarta. The DPRD stopped the discussion related to the Regional Regulation Draft (Raperda) of the Coastal Zone and Small Islands Zoning Plan (RZWP3K) and the Panturan Strategic Area Spatial Plan (RTRKS) due to the corruption case committed by Mohamad Sanusi as a member of the DPRD of DKI Jakarta. In this crime, he was convicted of corruption in the reclamation draft regulation from the former President Director of PT Agung Podomoro Land, Ariesman Widjaja [2]. 
Moreover, other issues have also arisen regarding environmental aspects. In general, the negative impacts caused by coastal reclamation are pollution of the coastal environment by the waste produced, changes in coastline of the current ocean patterns, fishermen activities being disrupted or even losing their livelihoods, potential flooding in the coastal area because of the 13 rivers that flow into the reclamation area, as well as coastal pollution during construction which causes a lot of biodiversities is predicted to be extinct if the reclamation project continues [3].

Data obtained from the Indobarometer Survey Institute shows that the reclamation project in North Jakarta is more likely to harm residents than it is profitable. Asep Saepudin as an Indobarometer researcher said that from the results of the survey, the reclamation project was considered detrimental to fishermen by $34.9 \%$ participants. Then, those who assumed damage to the environment by $31.9 \%$ followed by those who assumed that the reclamation could cause disastersn (flood/abrasion) by $19.2 \%$, those who assumed that the results only to be enjoyed by the rich (upper-middle class) by $5.2 \%$, those who assumed that this project would lead to corruption by $3.9 \%$, those who assumed that reclamation was throwing away the provincial government budget by $3.5 \%$, those who assumed there was a narrowing aquatic land (sea) by $0.9 \%$, and those who assumed that the reclamation only benefits the interests of the developer by $0.4 \%$. For these reasons, the majority of the community agreed that the Jakarta north coast reclamation project must be stopped [4].

The difference between Anies and Ahok's policies certainly cannot be separated from the 2017 election. That time, the reclamation of the north coast of Jakarta is a controversial policy during Ahok's leadership. This policy became a political commodity with the discourse of revoking the reclamation permit from Anies as one of his campaign promises made during the campaign period to fight Ahok, the incumbent. This is related to policy governance in good governance to measure the effectiveness of the process of public policy changes that occur. From this background, the researcher looked further at the causes of the policy changes and the subsequent impacts arising from the revocation of the 2018 Jakarta north coast reclamation permit.

\section{Theoritical Review}

\subsection{Public Policy}

According to Said Zainal Abidin, public policies are not specific and narrow, but broad and are at the strategic level. Therefore, the public policy serves as a general guideline for policies and special decisions under it [5]. While Thomas R. Dye defines that public policy is whatever governments choose to do or not to do [6]. Then, stopping the policy or changing the policy is one of the stages of phases in the public policy cycle. The stage of public policy consists of the stage of identifying problems or formulating public problems, preparing the agenda into a public policy agenda and formulating policies, then the stage of implementing the policy, and finally, conducting a policy assessment through evaluation and monitoring mechanism [7].

The cycle of a public policy begins with a problem and its formulation when policymaker who has the authority to identify problems that occur to the public then formulate it in the form of public policy. The next cycle is implementing the public policy that has been set for the community to solve a problem that occurs in the community. After that, the most 
important cycle is the policy evaluation stage. From this stage, we can assess and obtain an outcome from the public policy that has been implemented. The obtained evaluation results will be used as a reference for the preparation or amendment for improving the policy.

The final step of the policy cycle is to end the policy because the goal has been achieved or the policy has been replaced or changed with a new policy. Changes or termination of public policy is a deliberate decision by the government with a specific termination of the functions of government, policies, organizations with an evaluation of public policies that are considered by the government to make changes to the policy.

\subsection{Good Governance}

Governance is defined as the mechanisms, practices and procedures of governance and citizens governing resources and solving public issues. In the concept of governance, the government is only one actor and not always the decisive actor because there are other actors besides the government with a dominant role too [8]. Good governance is an ideal that is the basis of a vision in every implementation of state affairs in various countries such as Indonesia.

Related to the theory of good governance, Bhatta said there are 4 main elements contained in it which is (1) accountability, (2) transparency, (3) openness, and (4) the rule of law [9]. in further developments, UNDP, as quoted by the State Administrative Agency in Widodo, explained that there were 9 characteristics of good governance which are explained as follows [10]:

1. Participation

2. Rule of law

3. Transparency

4. Responsive

5. Orientation consensus

6. Equality

7. Effektive and efficient

8. Accountability

9. Strategic vision [11].

Therefore, it can be concluded that there is an improvement in the characteristic development of good governance. At least, there are 9 characteristics of good governance that have been explained above. The more characteristics of good governance that are fulfilled by the administration of government mean that the government system is getting better.

\section{General Description of Research Objects}

\subsection{General Description of North Jakarta Region}

The development of the north coast strategic area or reclamation consider the detailed regional spatial plan that borders directly with several sub-districts in the North Jakarta City Administration region, including Penjaringan Sub-District, Pademangan Sub-District, Tanjung Priok Sub-District, Koja Sub-District and Cilincing Sub-District to create integrated spatial planning and directions for the use of space in the context of revitalizing the old coast. The North Coast of Jakarta is located in the northern part of DKI Jakarta, which covers the water 
area in the Jakarta Bay, which includes the area of DKI Jakarta and is bordered by the existing coastal land area. Administratively, the North Coast of Jakarta area is part of the North Jakarta City Administration. In general, the northern coast of Jakarta covers the waters area, where 5.218 ha of which are planned to be developed as new land through reclamation in the form of islands separated from the mainland of DKI Jakarta Province [12].

Relatively, the water area is bordered by the northern coastline of DKI Jakarta Province along $\pm 32 \mathrm{~km}$, in the western part border with the north coast of Tangerang District and in the eastern part border with the north coast of Bekasi District. The coastal area in the north of DKI Jakarta Province includes parts of Penjaringan Sub-District, Pademangan Sub-District, Tanjung Priok Sub-District, Koja Sub-District, and Cilincing Sub-District [13].

\subsection{The Profile of Jakarta North Coast Reclamation}

The location of the North Coast of Jakarta makes it access between the mainland area and the Thousand Islands and various activities and activities that pass through or are in the Java Sea. Thus, the north coast of Jakarta also functions as a transshipment point for sea and land transport modes on a larger scale from the city of Jakarta. In this area, there are many transportation activities, such as Tanjung Priok port, Sunda Kelapa port, Marina Ancol, MRT station plans, toll roads, and other arterial road networks. The reclamation area of the north coast of Jakarta has around 5.100 ha, which is divided into three sub-regions;

1. The western sub-region as a moderate intensity residential area, recreational/tourism activities and limited commercial activities.

2. Central sub-region as a trading center/international service scale, recreational/tourism center and high-intensity residential area.

3. The eastern sub-region as a center for the distribution of goods, ports, industries/warehousing, and low-intensity residential area as a support [14].

The reclamation area includes the coastal area of Jakarta Bay which is measured from the northern coastline of Jakarta perpendicular to the sea to the line connecting the outermost points that show the depth of the sea 8 (eight) meters and there is a new land development area through island development resulting from reclamation activities. The area of the North Coast of Jakarta is part of the North Jakarta City Administration and it is located in the waters of the Jakarta Bay which situated between 106 $43^{\prime} 10^{\prime \prime}$ East Longitude, 6²2'55" South Latitude$106^{\circ} 57^{\prime} 40^{\prime \prime}$ East Longitude, 5'47'30" South Latitude, with the following borderline:

a) On the north, it is bordered by the Sub-district of South Thousand Islands, District administration of the Thousand Islands, DKI Jakarta Province.

b) On the West, it is bordered by Kosambi Sub-district, District of Tangerang.

c) On the East, it is bordered by Tarumajaya Sub-district, Bekasi District.

d) On the South, it is bordered by Penjaringan Sub-district, Pademangan Sub-district, Tanjung Priok Sub-district, Koja Sub-district, and Cilincing Sub-district, North Jakarta City Administration. 


\section{Research Result and Discussion}

\subsection{The Policy Change of DKI Jakarta in Revoking the 2018 Jakarta North Coast Reclamation Permit}

\subsubsection{The Reclamation Permit Policy of North Coast of Jakarta Period of Basuki Tjahaja Purnama (Ahok)}

In 2012 the governor of DKI Jakarta Fauzi Bowo issued Governor Regulation number 121 of 2012 about spatial planning of the reclamation area of the North Coast of Jakarta. Through this regulation, the reclamation design has changed to the formation of 17 new islands where these islands will be used as a residential area, tourism, trade, and distribution of goods. After that, the leadership position in Jakarta changed, in the new leadership administration, the DKI Jakarta Provincial Government issued principle permit to each of the artificial island developers. Ahok served DKI Jakarta from 2014 to 2017 replacing Jokowi (governor of DKI Jakarta in 2012-2014) who rose to become President. The issuance of these 4 decrees means that there are already four developers who can continue the activity of reclamation development according to the rules and the land use of each island. The 4 decrees on the permit stated in the Gubernatorial Decree namely:

a. Gubernatorial Decree No. 2238 of 2014 concerning the permit of the reclamation project of the island of G to PT Muara Wisesa Samudera, published on December 23, 2014.

b. Gubernatorial Decree No. 2268 of 2015 concerning the permit of the reclamation project of the island of F to PT Jakarta Propertindo, published on October 22, 2015.

c. Gubernatorial Decree No. 2269 of 2015 concerning the permit of the reclamation project of I island to PT Jaladri Kartika Pakci, published on October 22, 2015.

d. Gubernatorial Decree No. 2485 of 2015 concerning the permit of the reclamation project of K island to PT Pembangunan Jaya Ancol, Tbk, published on November 17, 2015.

In 2015, the DKI Jakarta Provincial Government under the leadership of Governor Ahok prepared for the initial stages of developing other reclamation islands. Islands $\mathrm{O}, \mathrm{P}$ and $\mathrm{Q}$ will be integrated with island $\mathrm{N}$ for the construction of the Port of Jakarta. In its dynamics, the reclamation project is causing many pros and cons and push and pull between the central government and the DKI Jakarta Provincial Government related to the continuation of the reclamation project. However, in the middle of the project, there was a bribery case of DKI Jakarta DPRD member Muhammad Sanusi with the President Director of Agung Podomoro Land linking the two with the reclamation project. The case arose and made the public focus on the reclamation of the North Coast of Jakarta, so the project had to be stopped for a while.

Later on, in the 2017 DKI Jakarta election campaign, Anies promised to stop the reclamation project and after he was elected, under the new leadership, Anies Baswedan began to study all aspects of reclamation and began implementing his promise by sending a letter to the DPRD that the regional regulatory plan (Raperda) RTRKS was revoked because there is no discussion about it anymore in the DPRD. At that time, the governor of DKI Jakarta, Anies Baswedan revoked 2 Draft Regulation or Regional Regulation Plan, namely the Regional Regulation Plan of North Coast of Jakarta and Draft Regional Zoning Plan for Coastal Areas and Small Islands (RZWP3K) because according to him, the draft was no longer relevant to the current condition of Jakarta and it would be reviewed by the executive before being discussed further in the legislative. 
The long history of reclamation with the dynamics of full pros and cons which is considered having ended in 2018, with the revocation of reclamation permit policy of North Coast of Jakarta carried out by the 2018 governor of DKI Jakarta. With the revocation of permits on these 13 reclamation islands, the fishing community which has always opposed and trying to reject the reclamation project felt that it was helpful because the DKI Jakarta Provincial Government had finally considered all aspects of advocacy done by the community related to the reclamation project which had been detrimental to them not only from environmental aspects but also from the livelihood aspects. But, the revocation of permits on the 13 reclamation islands is also considered not detrimental to the private sector or developers, because basically the developers have not yet carried out development on the 13 islands.

\subsubsection{The Revocation of the Reclamation Permit of The North Coast of Jakarta in 2018}

The reclamation of the North Coast of Jakarta in its journey continues to receive supervision from various parties in which there are also many pros and cons to the policy. Everyone may express their views regarding the reclamation policy of the North Coast of Jakarta, which may directly be related to most people in the coastal area.

The argument of people or parties who don't agree with Jakarta's north coast reclamation is that Jakarta's north coast reclamation should not be continued anymore because in the environmental aspects of the coastal area, it adds a lot of environmental problems. Technically, there are also many facts found that by doing the reclamation in Jakarta bay, there will be a slowdown in river flow so that it increases sedimentation. Therefore, there is also a contradictory opinion which explains that the reclamation development is very proupper-middle and not oriented towards small fishermen, due to the fact that small fishermen must go to sea further [15].

Otherwise, people who agree or pro people toward Jakarta's north coast reclamation also have their own argumentation. They consider that the central government or the provincial government of Jakarta needs a new economic growth which means to encourage more positive or higher economic growth. Thus, new economic growth centers are developed. Through the development of a strategic area north coast of Jakarta. Then with the development of the 17 reclamation islands, the Jakarta bay will become more organized and some will take care of it. The following are the factors driving the revocation of the Jakarta north shore reclamation permit policy:

\section{a. Movement of Rejection}

During the process and project of Jakarta's north coast reclamation, there is result of sustainability transition, namely advocacy in a network-based context. The advocacy network is incorporated in the name of the Save the Jakarta Bay Coalition (KSTJ) which includes Walhi, KNTI, LBH Jakarta, Women's Solidarity, Kiara, the Indonesian Center for Environmental Enforcement (ICEL), and experts or experts are also included as well as loose groups who can support or challenge this reclamation project. At one point, there were various kinds of efforts, from organizing the community to organizing public opinion formation in this case.

\section{b. Scientific Research}

Land subsidence in Jakarta continues to decline which is not able to control. Every year, the land surface of Jakarta decreases between 18-26 cm. With this decline, Jakarta, which is already prone to flooding, is increasingly threatened by flooding. Reclamation projects can also increase the potential for flooding and inundation in coastal areas. 
Reclamation has an impact on ecosystems which will cause flooding because there are 13 rivers that flow in the north coast of Jakarta as well as a major impact on the lives of people in coastal areas. It is because most people work as traditional fishermen who depend on fish catches and other resources such as shellfish and seaweed.

\section{c. Campaign Promises}

In the local elections of Jakarta 2017, Anies declared a campaign promise that he would stop Jakarta's north coast reclamation. It became politic commodity in Jakarta's local elections in 2017. Thus, Political factors in this case are important benchmarks in pushing the revocation of the 2018 Jakarta's North Coast reclamation permit to be carried out in accordance with the campaign promises delivered in the Jakarta Local Election by selected governor, Anies Baswedan to stop Jakarta's north coast reclamation by conducting revocation of permits for 13 islands reclaiming Jakarta's north coast reclamation.

\subsubsection{Revocation of Permit Policy of Jakarta's North Coast Reclamation 2018 Period of Anies Baswedan}

The issued of governor's regulations number 58 Year 2018 by Province Government of Jakarta on June 4, 2018 under the leading of Anies Baswedan, it was the beginning of issuing the revocation policy of the 2018 Jakarta north coast reclamation permit. Governor Regulation number 58 Year 2018 concerning the formation, organization, and working procedures of the coordinating body for the management of Jakarta's North Coast Reclamation was formed with various considerations of the existing legal provisions. This regulation was formed as a form of governor Anies wishing to carry out an in-depth audit or inspection of the island of the island in the planned reclamation of Jakarta's North Coast Reclamation.

Based on governor's regulation of 58 Year 2018, Anies and Jakarta Province Government took new decision which was revoking permits of 13 reclaimed islands on Jakarta's North Coast Reclamation. The 17 islands that have been audited by BKP Pantura and the verification results state that 13 reclamation islands have not shown a reclamation process on the island, and 4 other islands have been reclaimed and a new land has been formed. The results of the verification were then made by Anies as a finding that was considered to implement its political promise to stop the reclamation process on Jakarta's North Coast Reclamation against 13 islands which had been examined by BKP Pantura.

The policy to revoke the reclamation permit of Jakarta's North Coast Reclamation to the 13 reclamation islands was decided by the Governor of DKI Jakarta, Anies Baswedan on September $26^{\text {th }} 2018$ through a press conference held by the DKI Jakarta Provincial Government in the City Hall Building. The policy is then contained in the form of legal products in the form of a decree and the governor's decision as follows:

a. Decree of DKI Jakarta Governor Number 1409 Year 2018 about revocation of several governors' decisions regarding the granting of reclamation permits, issued on September 6, 2018.

The decree of governor was issued based on the consideration due to the expiration of the validity period of the reclamation permit which has not yet produced an island, the governor has the right to revoke the reclamation permit for the north coast of Jakarta.

The decree of governor explains island F with the developer PT Jakarta Propertindo, island $\mathrm{H}$ with the developer PT Taman Harapan Indah, and island I with the developer PT Jaladri Kartika Paksi revoked the licenses they had received respectively in governor decree number 2268, 2637 and 22692015. 
b. Decree of DKI Jakarta Governor Number 1410 year 2018 about Revocation of the Governor's Decree Number 2485 of 2015 concerning Granting K Island Reclamation Permit to PT Pembangunan Jaya Ancol, Tbk., issued on September 6, 2018.

This policy was also carried out on the basis of the consideration that the reclamation permit will expire and the reclamation permit is not possible in the remaining period of reclamation settlement and according to the results of the meeting of the leadership of the regional spatial coordination coordinating body on August 9, 2018, the revocation of the reclamation permit is conducted.

And a number of similar legal products through the governor's decree also focuses on the revocation of the reclamation permit of the 2018 Jakarta's north coast reclamation against the islands A, B, E, J, L, M, O, P, and Q with each developer PT Kapuk Naga Indah, PT Pembangunan Jaya Ancol, PT Jakarta Propertindo, PT KEK Marunda Jakarta, and PT Manggala Krida Yudha.

After some law products of DKI Jakarta governor policy above focusing on the revocation of the reclamation permit for Jakarta's north coast reclamation, Jakarta governor also announced the follow-up of the 4 other islands which had been formed that land management on the islands C, D, and G was handed over to the BUMD namely PT Jakarta Propertindo (Jakpro). Meanwhile, Pulau N and the developer of PT Pelindo 2 are clearly designated as new ports or docks at the Tanjung Priok port, North Jakarta. Then the Jakarta governor's decree was also issued in 2018 number 1744 regarding the naming of our coastal areas, developed coastal areas, and coastal areas along with the administrative city of North Jakarta.

Decree of DKI Jakarta Governor is issued based on the consideration in order to realizing the orderly administration of the territorial management with the increase of the coastal area in the administration city of North Jakarta, the naming of the coastal area has been determined as a result of the reclamation process. Our coastal area as a mention for the reclamation of island C, located in the Kamal Muara sub-district Penjaringan subdistrict, North Jakarta administration city, then the developed coastal area as a mention for the reclamation results of island D which is located in Kamal Muara sub-district, Penjaringan sub-district, North Jakarta city administration, and the coastal area together as a mention for the results of the reclamation of the island of $\mathrm{G}$ which is located in the Pluit village, Penjaringan subdistrict, North Jakarta administration city.

\subsection{The Impact of DKI Jakarta Governor in Permit Revocation of Jakarta's North Coast Reclamation 2018}

\subsubsection{The Impact of Environment}

The policy of DKI Jakarta governor about permit revocation of Jakarta's north coast reclamation seems not to give significant changes to the environment in the coastal areas of Jakarta. The termination of the reclamation project of the north coast of Jakarta is indeed a stage of achievement towards the ideals of the ideal environment, but has not been able to answer the environmental problems that exist in Jakarta's north coast reclamation.

Environmental Office (DLH) of DKI Jacarta Province conducts researches toward 3 islands. The findings explain that waste disposal time has increased from 6 days to 12 days, which means the refusal of waste has become longer to $1.2 \mathrm{~km}$, which previously dis not reach that number. Furthermore, there is sedimentation proven to cause floods and all kinds of other disastrous impacts. Beside, a decrease in land surface that occurs between 1 to $9 \mathrm{~cm}$ every year. Thus, actually behind this large project, it is not only the developers of 13 other islands 
that did not carry out their obligations but also proved in the 3 islands that have been built also have a lot of negative impacts on the ecosystem and the environment [16].

\subsubsection{Impact of Economy}

The revocation of permission of 13 islands, the developers feel disadvantaged because the termination of the reclamation project has an impact on the movement of developer shares. PT Intiland Development and PT Pembangunan Jaya Ancol have been on the Indonesia Stock Exchange. After Anies decided to stop the reclamation project, Intiland's share price fell. The same condition also occurred in Ancol shares which declined after the announcement of the revocation of the reclamation permit for Jakarta's north coast reclamation.[17] The DKI Jakarta Provincial Government has also lost a new source of income or APBD revenue from the contribution of the developer given lost new jobs or other greater investment if the 17 islands of the reclamation of Jakarta's north coast reclamation are continued. However, this needs to be conducted in order to enforce environmental laws in a sustainable manner.

On the other side, after the policy of DKI Jakarta governor about revocation of the reclamation permit for Jakarta's north coast, there is a change in the impact that is more positive for the economy of the coastal communities who felt directly the impact of the new policy. After the termination of Jakarta's north coast reclamation project was terminated with the revocation of the 2018 Jakarta north coast reclamation permit policy, there is an increase in income that could be directly felt in real positive impact. Before this policy, the fishermen went out to sea to farther because the level of turbidity of the water increased.[18]

\subsubsection{Impact of Partnership}

The policy of DKI Jakarta governor about revocation of permits on 13 reclamation islands indirectly impacts the developers who have held such permits before. The 13 reclaimed islands that licenses were revoked are owned by seven developers namely PT Jaladri Kartika Paksi island I, PT Jakarta Propertindo island F, PT KEK Marunda Jakarta islands O, P and Q, PT Kapuk Naga Indah (son of Agung Sedayu Group) islands A, B, and E, PT Manggala Krida Yudha islands L and M, PT Taman Harapan Indah (a subsidiary of PT Intiland Development) island $\mathrm{H}$, and PT Pembangunan Jaya Ancol islands $\mathrm{J}$ and $\mathrm{K}$. The developers revealed that the most felt loss was a loss of time, the article of the company have planned and collaborated with other parties.

Even though the developer feel disadvantaged because of the revocation of the reclamation permit, the DKI Jakarta Provincial Government is ready to provide compensation, especially for developers who have made additional contributions, such as flats, roads, and other infrastructure. During the process of developing the pros and cons of the new DKI Jakarta governor's policies, the DKI Jakarta Provincial Government as a government party in the reclamation of the north coast of Jakarta has carried out the procedure for revoking permits for the reclamation of the north coast of 2018 in accordance with applicable governance principles and principles.

\section{Conclusion}

Therefore, DKI Jakarta governor, Anies Rasyid Baswedan can pay off his campaign promise to stop the reclamation. He revoked the 13 islands that have held a reclamation project permit so that it is not forwarded or reclaimed into new land and designated 4 islands that have been built for the benefit of the community and they are open to people who have now been named by the Governor of DKI Jakarta namely Kita Beach (Pulau C), Maju Beach 
(Pulau D), and Bersama Beach (Pulau G), and Tanjung Priok Harbor Pier (Island N). However, there is a need for further processes to further legalize the policy so that there are no claims that allow the resumption of reclamation projects that have been revoked.

\section{References}

[1] Erwin Dariyanto, "23 Janji Anies Baswedan Sandiaga Uno KJP Plus Sampai Setop Reklamasi”, https://news.detik.com/berita/d-3341915/23-janji-anies-baswedan-sandiaga-uno-kjp-plus-sampaisetop-reklamasi, diakses pada 17 Januari 2019

[2] Bayu Nanda Permana, "Konflik dalam Kebijakan Reklamasi Teluk Utara Jakarta pada Masa Pemerintahan Basuki Tjahaja Purnama (Ahok) Periode 2015-2017”, (Skripsi Ilmu Poltik FISIP: UIN Syarif Hidayatullah Jakarta, 2018).

[3] Flora Kalalo, Implikasi Hukum Kebijakan Reklamasi Pantai dan Laut di Indonesia, (LoGoz Publishing, 2009), 5. Dalam Olivianty Reulla, "Proses Perizinan dan Dampak Lingkungan Terhadap Kegiatan Reklamasi Pantai”, (Jurnal Lex Administratum Vol. 1, No. 2, Tahun 2013).

[4] Hery H Winarno, "Survei Indo Barometer: Mayoritas Warga Tolak Reklamasi Teluk Jakarta", https://www.merdeka.com/jakarta/survei-indo-barometer-mayoritas-warga-tolak-reklamasi-telukjakarta.html, 10 November 2018.

[5] Said Zainal Abidin, Kebijakan Publik, (Jakarta: Salemba Humanika, 2012), hlm. 7.

[6] Sahya Anggara, Kebijakan Publik, (Bandung: CV Pustaka Setia, 2014), hlm. 35.

[7] William N. Dunn, Pengantar Analisis Kebijakan Publik, (Yogyakarta: Gadjah Mada University Press, 2003).

[8] Sumarto Hetifa Sj, Inovasi, Partisipasi dan Good Governance, (Bandung: Yayasan Obor Indonesia, 2003), hlm. 1-2.

[9] Gambhir Bhatta, Capacity Building at The Local Level for Effective Governance, Empowerment Without Capacity is Meaningless, (Paper presented in The International Conference on Governance Innovation: Building The Government Citizen Business Partnership; October 20-23 1996), 7.

[10] Joko Widodo, Good Governanve: Telaah dan Dimensi Akuntabilitas dan Kontrol Birokrasi pada Era Desentralisasi dan Otonomi Daerah, (Surabaya: Insan Cendikia, 2001), hlm. 26.

[11] Joko Widodo, Good Governanve: Telaah dan Dimensi Akuntabilitas dan Kontrol Birokrasi pada Era Desentralisasi dan Otonomi Daerah.

[12] Materi Teknis Raperda RTRKS (Rencana Tata Ruang Kawasan Strategis) Pantura Jakarta 2015.

[13] Materi Teknis Raperda RTRKS Pantura Jakarta 2015.

[14] Bahan Paparan Seminar Internasional tentang pengembangan kawasan teluk Jakarta, diselenggarakan oleh IWI (Indonesia Water Institute) di Jakarta).

[15] Wawancara dengan Feirully Irzal, Kabid P4 Bappeda Pemprov DKI Jakarta pada 20 Maret 2019 di Gedung Balai Kota Pemprov DKI Jakarta.

[16] Wawancara dengan Irfan Pulungan, Anggota TGUPP Bidang Pesisir Pemprov DKI Jakarta pada 13 Mei 2019 di Gedung Balai Kota Pemprov DKI Jakarta.

[17] Ringkang Gumiwang, "Rugi Pengembang di Tanah Reklamasi”, https://tirto.id/rugi-pengembangdi-tanah-reklamasi-c387, 1 Juli 2019.

[18] Wawancara dengan Marthin Hadiwinata, Ketua DPP Kesatuan Nelayan Tradisional Indonesia (KNTI) pada 19 Juni 2019 di Rumah Nelayan KNTI, Pasar Minggu, Jakarta Selatan. 